DOI: $10.15593 / 2224-9982 / 2015.40 .03$

УДК 661.666:66.023

\author{
В.М. Бушуев, С.Г. Лунегов, М.В. Бушуев
}

ОАО «Уральский научно-исследовательский институт композиционных материалов», Пермь, Россия

\author{
РАЗРАБОТКА КОМБИНИРОВАННОГО МЕТОДА \\ СИЛИЦИРОВАНИЯ КРУПНОГАБАРИТНЫХ ИЗДЕЛИЙ \\ ИЗ УУКМ, БАЗИРУЮЩЕГОСЯ НА АЛЬТЕРНАТИВНОМ \\ ЖИДКОФАЗНОМ МЕТОДЕ И ПРИМЕНЕНИИ ПРОЦЕССА \\ КАПИЛЛЯРНОЙ КОНДЕНСАЦИИ ПАРОВ КРЕМНИЯ
}

\footnotetext{
Описаны особенности реализации комбинированного метода силицирования крупногабаритных заготовок из углерод-углеродного композиционного материала. Его сущность состоит в сочетании альтернативного жидкофазного метода, где прекурсором жидкого кремния выступает нитрид кремния, и парожидкофазного метода, заключающегося в испарении кремния и последующей конденсации его паров в порах материала заготовки. Положительные результаты объемного силицирования были обеспечены проведением процесса капиллярной конденсации паров кремния в интервале температур 1300-1550 ${ }^{\circ} \mathrm{C}$ при наличии перепада температур между температурой паров кремния и температурой заготовки. Образцы из углерод-карбидокремниевого материала с высокой степенью силицирования и с высокой чистотой поверхности получены при реализации комбинированного метода силицирования в два этапа. На первом этапе осуществлялся процесс капиллярной конденсации паров кремния в нагревателе, обеспечивающем более высокую температуру на тиглях с кремнием по сравнению с температурой на силицируемой заготовке; на втором этапе - процесс пропитки материала заготовки жидким кремнием, образующимся при разложении нитрида кремния в нагревателе с равномерным распределением температур по его высоте.

Ключевые слова: заготовка из углерод-углеродного композиционного материала, силицирование, пар кремния, нитрид кремния, жидкий кремний, углеродсодержащий газ, капиллярная конденсация, перепад температур, изотермическая выдержка, жидкофазная пропитка.
} 


\author{
V.M. Bushuev, S.G. Lunegov, M.V. Bushuev \\ OJSC "Ural Research Institute of Composite Materials", \\ Perm, Russian Federation
}

\title{
DEVELOPMENT OF A COMBINED METHOD OF SILICONISING OF LARGE-SIZED CCCM PRODUCT BASED ON ALTERNATIVE LIQUID-PHASE METHOD AND PROCESS OF CAPILLARY CONDENSATION OF SILICON VAPOURS
}

\begin{abstract}
The features of the combined method of siliconising large-sized blanks of the carbon-carbon composite material (CCCM) is described. Its essence is the combination of alternative liquid-phase method, where the precursor of liquid silicon is silicon nitride, and vapor-liquid-phase method, which consists in evaporation of silicon and subsequent condensation of its vapors in the pores of the material blank. Positive results of volumetric siliconising is provided by the process of capillary condensation of silicon vapours in the $1300-1550^{\circ} \mathrm{C}$ temperature range in the presence of a temperature difference between the temperature of the silicon vapor and the temperature of the blank. Samples of carbonsilicon carbide material with a high degree of siliconising and high surface finish is obtained in two stages by the combined method of siliconising. The first stage is the process of capillary condensation of silicon vapours in heater providing a higher temperature in the crucible with silicon as compared with the temperature at siliconized bulk. The second stage is the process of impregnation of the material with liquid silicon, formed by the decomposition of silicon nitride in the heater with uniform temperature distribution along its height.
\end{abstract}

Keywords: CCCM blank, siliconising, silicon vapor, silicon nitride, liquid silicon, carbon gas, capillary condensation, temperature difference, isothermal aging, liquid-phase impregnation.

\section{Введение}

Одним из экономичных процессов изготовления изделий из углерод-карбидокремниевых материалов (УККМ) является процесс силицирования.

Наиболее простым с точки зрения аппаратурного обеспечения процесса силицирования крупногабаритных и сложнопрофильных изделий из углерод-углеродного композиционного материала (УУКМ) жидкофазным методом является шликерный метод ${ }^{1}$ [1], в котором на

${ }^{1}$ Способ получения изделий из углерод-карбидокремниевого композиционного материала и углерод-карбидокремниевый композиционный материал: пат. РФ № 2084425, МПК С04В35/52, С04В35/83, С04В35/56 / Гос. науч.-исслед. ин-т конструкционных материалов на основе графита. - 92015952/03; заявл. 30.12.1992; опубл. 20.07.1997. 
поверхности заготовки из УУКМ формируется шликерное покрытие на основе композиции из порошка кремния и временного связующего.

Обязательным условием обеспечения объемного силицирования изделий из УУКМ данным методом является необходимость нагрева до температур 1300-1700 ${ }^{\circ} \mathrm{C}$ со скоростью 600-800 град/ч [1] для существенного уменьшения науглероживания расплава кремния и сохранения тем самым его низкой вязкости.

Реализовать такую высокую скорость нагрева применительно к крупногабаритным изделиям не представляется возможным. Силицирование с реально достижимыми невысокими скоростями нагрева носит поверхностный характер и приводит к образованию наростов на силицируемых деталях.

Решением проблемы могло бы стать использование парожидкофазного метода [2], при котором нет необходимости производить нагрев со скоростью 600-800 град/ч. Однако существенным недостатком данного метода при проведении его в установках изотермического нагрева является плохая его воспроизводимость от процесса к процессу.

Отпадает необходимость в высокоскоростном нагреве также при использовании альтернативного метода жидкофазного силицирования [3-5], в котором в качестве силицирующего агента используется жидкий кремний, образующийся при разложении нитрида кремния, который наносится на поверхность силицируемой детали в виде шликерного покрытия.

При проведении силицирования данным методом при атмосферном давлении разложение нитрида кремния происходит при температуре $1700-1750{ }^{\circ} \mathrm{C}$, причем образуется жидкий кремний в количестве $100 \%$ от стехиометрического.

Однако при таких температурах кремний имеет высокую химическую активность, из-за чего возникает опасность частичной карбидизации углеродных волокон, особенно в местах дефицита углеродной матрицы.

Известен комбинированный метод силицирования на основе альтернативного жидкофазного метода в присутствии паров кремния ${ }^{2}$ [6]. В процессе силицирования данным методом в вакууме разложение

${ }^{2}$ Способ изготовления изделий из углерод-карбидокремниевых материалов: пат. РФ №2458889: МПК С04В35/573 / В.М. Бушуев. - 2011107655/03; заявл. 28.02.11; опубл. 20.08.12. 
Комбинированный метод силицирования крупногабаритных изделий из УУКМ

нитрида кремния происходит при температуре $1600-1650{ }^{\circ} \mathrm{C}$; причем образуется $60 \%$ паров и $40 \%$ жидкого кремния. При этом на стадии охлаждения заготовки открытые поры материала заполняются кремнием (преимущественно свободным) за счет конденсации паров кремния на поверхности и/или непосредственно в порах материала.

Однако в этом случае существует реальная опасность частичной карбидизации частиц нитрида кремния в шликерном покрытии в период нагрева до температуры его разложения, если состояние паров кремния из-за утечки их в стыки реторты не является насыщенным. Обусловлено это увеличением скорости диффузии углеродсодержащих реакторных газов при переходе от атмосферного давления к вакууму.

Более того, при ненасыщенном состоянии паров кремния при разложении нитрида кремния образуются преимущественно пары, а не жидкий кремний. При этом происходит поверхностное силицирование заготовки, в результате чего получим лишь поверхностно силицируемое изделие, как в случае силицирования классическим жидкофазным методом [1].

Таким образом, видно, что результаты силицирования напрямую зависят от степени насыщенности паров кремния; причем, чем ближе состояние паров кремния к давлению насыщенных паров, тем выше степень силицирования УУКМ.

Однако в крупногабаритных установках изотермического нагрева при проведении процесса силицирования возникают трудности с созданием условий для образования насыщенного состояния паров кремния и управления им. Обусловлено это тем, что по мере удаления от источников паров кремния давление их уменьшается $[7,8]$, а также утечкой их в вакуумную систему через проницаемые стыки реторты [8]. Именно это обстоятельство делает практически невозможным протекание процессов конденсации паров кремния в реальных условиях проведения процесса силицирования в установках изотермического нагрева, из-за чего не обеспечивается получение стабильно высоких результатов по степени и равномерности силицирования.

Это послужило основанием для разработки такого варианта комбинированного метода силицирования, в котором бы гарантированно обеспечивалось пересыщенное состояние паров кремния (по крайней мере до получения жидкого кремния из порошка нитрида кремния), 
а также возможность регулирования величины пересыщенного состояния паров кремния в окрестности силицируемой заготовки.

\section{Предпосылки к усовершенствованию технологии силицирования комбинированным методом}

Комбинированный метод силицирования представляет собой сочетание альтернативного жидкофазного метода с парожидкофазным методом. В первом из них в качестве прекурсора жидкого кремния выступает порошок нитрида кремния или кремний в оболочке (капсуле) из нитрида кремния, который наносится на поверхность силицируемой детали в виде шликерного покрытия. При втором методе массоперенос кремния в поры материала осуществляется посредством конденсации паров кремния из газовой фазы реактора, в котором размещены тигли с кремнием.

В соответствии с работой [9] существует три типа конденсации: конденсация в объеме реактора, конденсация на поверхности, конденсация непосредственно в порах материала; последнюю еще называют капиллярной конденсацией. Применительно к разрабатываемому варианту комбинированного метода силицирования особый интерес представляет капиллярная конденсация паров кремния. Известно, что для получения высокой степени силицирования УУКМ процесс заполнения пор кремнием необходимо начать с самых мелких по размерам и постепенно распространять на более крупные поры. Для этого целесообразно начать создание пересыщенного состояния паров кремния со сравнительно низких температур, так как для заполнения кремнием мельчайших пор требуется самая низкая степень пересыщения. Можно предположить, что температура на силицируемой заготовке $(1350 \pm 20){ }^{\circ} \mathrm{C}$ приемлема для протекания конденсации паров кремния в мелких порах, так как для их заполнения требуется наиболее низкая степень пересыщения паров. Следует заметить, что при данной температуре протекает именно капиллярная конденсация паров кремния. Это следует из того, что при температуре ниже температуры плавления кремния невозможна ни капиллярная пропитка конденсатом паров кремния, ни пропитка расплавом кремния.

Таким образом, капиллярную конденсацию паров кремния при реализации комбинированного силицирования предполагали осущест- 
Комбинированный метод силицирования крупногабаритных изделий из УУКМ

вить на стадии нагрева заготовки в интервале температур $1300-1550{ }^{\circ} \mathrm{C}$ за счет создания разницы температур между парами кремния и заготовкой, с проведением изотермических выдержек в указанном интервале температур.

Проведение нагрева заготовки ступенчато, с изотермическими выдержками в указанном интервале температур в совокупности с использованием в качестве силицирующего агента нитрида кремния или капсулированного в нитридкремниевой оболочке кремния и наличием разности температур между температурой тиглей с кремнием и температурой силицируемой заготовки должно обеспечить реализацию процесса конденсации паров кремния как в порах материала заготовки, так и в порах материала шликерного покрытия. Причем необходимо так реализовать указанный процесс, что заполненными карбидом кремния и кремнием должны оказаться мельчайшие, мелкие, а также частично средние и крупные поры материала заготовки, а материал шликерного покрытия уплотняется конденсатом паров кремния настолько, что практически исключается вероятность его карбидизации под воздействием углеродсодержащих реакторных газов (которые к тому же частично связываются парами кремния). Слой карбида кремния, который образуется на поверхности крупных и средних пор, должен практически исключить науглероживание образовавшегося в результате разложения нитрида кремния жидкого кремния в момент пропитки им материала заготовки.

Кроме того, проведение процесса капиллярной конденсации паров кремния в указанном интервале температур должно позволить начать заполнение кремнием с пор наименьшего размера, а также в процессе его карбидизации вскрыть бо́льшее количество закрытых пор материала заготовки и тем самым увеличить степень карбидизации углеродсодержащей матрицы в материале силицируемой заготовки.

Исходя из вышесказанного можно предложить следующую реализацию процесса силицирования комбинированным методом, обеспечивающим возможность исключения карбидизации частиц нитрида кремния в шликерном покрытии, а также карбидизации жидкого кремния за счет проведения нагрева с 1300 до 1650-1700 ㄷ при температуре паров кремния, превышающей температуру заготовки.

Вначале на заготовке из УУКМ формируют шликерное покрытие на основе композиции из порошка нитрида кремния или капсулированного в нитридкремниевой оболочке кремния и временного связую- 
щего. После этого заготовку и тигли с кремнием размещают в замкнутом объеме реторты. Затем осуществляют нагрев заготовки. При этом с 1300 до $1500-1550{ }^{\circ} \mathrm{C}$ нагрев производят в вакууме в парах кремния при температуре тиглей с кремнием, превышающей температуру заготовки на $100-150^{\circ} \mathrm{C}$. Кроме того, нагрев заготовки рекомендуется производить ступенчато, с изотермическими выдержками в указанном интервале температур.

Затем продолжают нагрев заготовки с 1500-1550 до $1650-1700{ }^{\circ} \mathrm{C}$ при отсутствии перепада температур между парами кремния и заготовкой. В этот период происходит разложение нитрида кремния (самого́ по себе или в составе оболочки капсулированного кремния) с образованием жидкого кремния и пропитка им пористой заготовки. При этом пропитка заготовки жидким кремнием осуществляется во всем ее объеме, так как благодаря исключению карбидизации частиц нитрида кремния в шликерном покрытии и сравнительно высокой температуре образования жидкого кремния он имеет низкую вязкость, а благодаря наличию на стенках пор противодиффузионного карбидокремниевого покрытия не науглероживается в период пропитки им заготовки. В этот же период избыток жидкого кремния благодаря его низкой вязкости, обусловленной отсутствием в нем частичек карбида кремния, стекает с поверхности заготовки.

Затем производят нагрев заготовки с $1650-1700^{\circ} \mathrm{C}$ и выдержку при $1700-1850^{\circ} \mathrm{C}$ при отсутствии разницы температур между температурой тиглей с кремнием и температурой заготовки. В этот период завершается процесс карбидизации кремния. Затем производят охлаждение заготовки в вакууме в парах кремния, что сопровождается конденсацией паров кремния и заполнением открытых пор образовавшегося в результате выдержки при $1700-1850{ }^{\circ} \mathrm{C}$ углерод-карбидокремниевого материала.

Однако, для того чтобы процесс комбинированного силицирования эффективно реализовался, должны выполняться условия, при которых конденсация паров кремния в порах материала заготовки осуществляется максимально интенсивно. Во-первых, пары кремния должны находиться в пересыщенном состоянии в окрестности детали. Во-вторых, для реализации конденсации паров кремния на поверхности и в порах материала заготовки необходим перепад температур между парами кремния и силицируемой заготовкой с меньшей температурой на 
заготовке. В-третьих, заготовка должна быть единственной или по крайней мере наиболее интенсивной зоной конденсации паров кремния.

При существующей оснастке условия конденсации паров кремния не выполняются в полной мере. Обеспечить возможность эффективного управления процессом силицирования, а точнее - управления процессами конденсации паров кремния, можно за счет проведения их в специализированных установках, снабженных специализированной оснасткой.

Что касается специализированной установки, то она должна обеспечить создание разницы между температурой паров кремния и температурой силицируемой заготовки с меньшей температурой на последней ${ }^{3}$. Что касается специализированной оснастки, то первое, что необходимо сделать, это обеспечить существенное уменьшение проницаемости стыков между частями реторты, по крайней мере до температуры $1650-1700{ }^{\circ} \mathrm{C}^{4}$.

Низкая проницаемость стыков между частями реторты придаст процессу силицирования в целом и процессам конденсации паров кремния в частности бо́льшую управляемость, так как при создании пересыщенного состояния паров кремния отпадет необходимость введения поправки на снятие такого состояния паров кремния из-за утечки их в стыки, величина которой является неопределенной.

Кроме того, решением проблемы может быть специализированная оснастка для силицирования, в которой бы тигли с кремнием были сконсолидированы на дне реторты, а их нагрев до более высоких температур осуществлялся бы донным нагревателем, снабженным автономным источником питания 5 .

${ }^{3}$ Способ изготовления изделий из углерод-карбидокремниевых материалов: пат. РФ № 2464250: МПК С04В35/573 / В.М. Бушуев. - 2011107658/03; заявл. 28.02.11; опубл. 20.10.12.

${ }^{4}$ Способ регулирования проницаемости стыков между частями реторты в оснастке для силицирования изделий: пат. РФ № 2520171: МПК С23С16/24, В22F3/26 / ОАО «УНИИКМ». - 2012144877/02; заявл. 22.10.12; опубл. 20.06.14; Способ и устройство для металлирования изделий парожидкофазным методом и способ регулирования проницаемости стыков между частями реторты в указанном устройстве, решение от 20.08.2014 о выдаче патента: МПК С23C14/24, C23C14/56, B22F3/26 / ОАО «УНИИКМ». - 2012144879/02; заявл. 22.10.2012.

${ }^{5}$ Способ изготовления изделий из углерод-карбидокремниевых материалов, пат. РФ № 2458889: МПК С04В35/573. 
В таком случае требуемой величины перепада температур между температурой паров кремния и температурой силицируемого изделия, в том числе в требуемых интервалах, можно достичь за счет отключения питания на нагреватель, увеличения или уменьшения подаваемой на него мощности.

Техническое решение, приведенное в патенте ${ }^{6}$, предусматривает создание пересыщенного состояния паров металла (в частности, кремния) при реализации комбинированного метода металлирования. Оно предполагает поддержание более высокой температуры на тиглях с металлом в сравнении с температурой заготовки во всем интервале температур. Его конструктивно-технологическое обеспечение достаточно сложно в реализации.

Это явилось еще одним основанием для разработки более простого в реализации варианта силицирования комбинированным методом.

Ввиду отсутствия специализированной оснастки для силицирования экспериментальные исследования очередного варианта комбинированного метода силицирования проводили в установке ГФ-1 в два этапа: первый этап - реализация процесса капиллярной конденсации паров кремния в интервале температур 1300...(1500-1550) ${ }^{\circ} \mathrm{C}$ при наличии перепада температур между температурой тиглей с кремнием и температурой заготовки; второй этап - реализация жидкофазной пропитки материала заготовки жидким кремнием, продуктом разложения нитрида кремния (самого́ по себе или в составе оболочки капсулированного кремния) при отсутствии перепада температур.

\section{Реализация процесса конденсации паров кремния в порах УУКМ со сформированным на нем шликерным покрытием на основе порошка нитрида кремния}

Силицированию комбинированным методом были подвергнуты образцы в виде «таблеток» из УУКМ на основе каркаса из высокомодульной ткани УТ-900ПМ и коксопироуглеродного связующего. Материал такой структуры имел поры, существенно отличающиеся по размерам: от десятых микрона до нескольких сотен микрон с образовани-

6 Способ изготовления изделий из композиционных материалов: пат. РФ № 2516096: МПК С04В35/577, С04В35/528 / В.М. Бушуев. - 2012110742/03; заявл. 20.03.12; опубл. 27.09.13. 
ем большого количества протяженных межниточных пор (макропор) на границе нитей основы и утка ткани. В результате материал имел большое количество макродефектов, что могло привести к значительной неоднородности и снижению физико-механических характеристик [10]. Кроме того, при получении УУКМ (в ходе карбонизации углепластика) под воздействием температуры происходят процессы, связанные с усадкой матрицы, что выражается в образовании большого количества усадочных трещин [11].

Размеры образцов: диаметр - 20 мм, толщина - 3 мм. На одной из сторон образцов было сформировано шликерное покрытие на основе порошка нитрида кремния.

Первый этап реализации комбинированного метода силицирования заключался в нагреве образцов до $1300{ }^{\circ} \mathrm{C}$, проведении процесса капиллярной конденсации паров кремния в интервале температур $1300 \ldots(1500-1550){ }^{\circ} \mathrm{C}$ и охлаждении заготовки.

Кроме того, образцы были помещены в замкнутый объем реторты, чтобы уменьшить отток паров кремния в проницаемые стыки.

Для обеспечения возможности нагрева тиглей с кремнием до более высокой температуры, чем силицируемые образцы, силицирование проводили в специальном составном нагревателе (рис. 1), нижняя часть которого выполнена из УУКМ, в то время как верхняя - из графита.

Благодаря более высокому удельному электросопротивлению УУКМ в сравнении с графитом в нижней части реализуется бо́льшая мощность. Этому же способствует пропускание тока на некотором участке дна нагревателя. При этом сравнительно небольшой диаметр на-

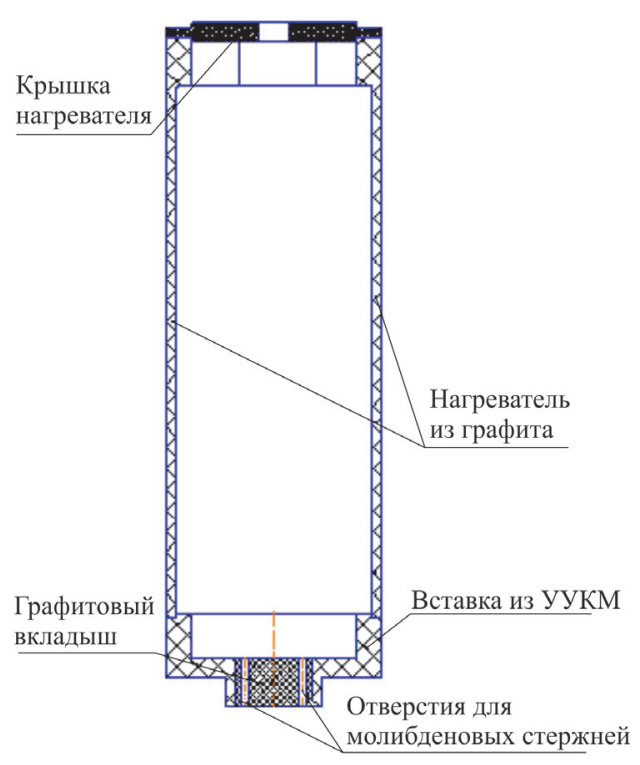

Рис. 1. Конструкция составного нагревателя гревателя вызывает необходимость подвода тока к его дну специальным токоподводом. Он выполнен из УУКМ и является продолжением дна нагревателя, точнее - выполнен с ним как одно целое. При этом, чтобы избежать чрезмерного перегрева токоподвода (из-за его сравни- 
тельно небольшого диаметра, точнее - проходного для тока сечения), он содержит графитовый вкладыш, в котором для уменьшения его сопротивления установлены молибденовые стержни. Главным недостатком данной конструкции нагревателя является невозможность управлять перепадом температур между заготовкой и тиглями с кремнием, т.е. процессом конденсации паров кремния.

После проведения обработки в режиме силицирования с образцов механическим методом было удалено шликерное покрытие и определены основные характеристики получившихся УККМ: плотность, открытая пористость и содержание кремния.

Результаты экспериментов с указанием технологических параметров процесса силицирования приведены в табл. 1.

Таблица 1

Результаты проведения капиллярной конденсации паров кремния в порах УУКМ со сформированным на нем шликерным покрытием на основе нитрида кремния

\begin{tabular}{|c|c|c|c|c|c|c|c|c|}
\hline \multirow[t]{2}{*}{$\begin{array}{l}\text { № } \\
\text { п/П }\end{array}$} & \multirow[t]{2}{*}{$\begin{array}{l}\text { Номер } \\
\text { образца }\end{array}$} & \multicolumn{2}{|c|}{$\begin{array}{c}\text { Основные } \\
\text { характеристики } \\
\text { пористого материала } \\
\text { заготовки }\end{array}$} & \multicolumn{2}{|c|}{$\begin{array}{c}\text { Технологические парамет- } \\
\text { ры процесса капиллярной } \\
\text { конденсации паров крем- } \\
\text { ния в интервале } 1300- \\
1550{ }^{\circ} \mathrm{C} \\
\end{array}$} & \multicolumn{3}{|c|}{$\begin{array}{c}\text { Основные } \\
\text { характеристики } \\
\text { УККМ }\end{array}$} \\
\hline & & \begin{tabular}{|c|} 
Плот- \\
ность \\
$\gamma$, г/см${ }^{3}$ \\
\end{tabular} & $\begin{array}{c}\text { Открытая } \\
\text { пористость } \\
\text { ОП, \% }\end{array}$ & $\begin{array}{c}\text { Температура на } \\
\text { заготовке, }{ }^{\circ} \mathrm{C}\end{array}$ & $\begin{array}{l}\text { Время вы- } \\
\text { держки, ч }\end{array}$ & $\gamma, \Gamma / \mathrm{cm}^{3}$ & $\begin{array}{c}\text { ОП, } \\
\%\end{array}$ & $\begin{array}{l}\text { Сод-е } \\
\text { Si, } \\
\text { вес. } \%\end{array}$ \\
\hline 1 & $1 / 6-3^{*}$ & 1,44 & 11,4 & $\begin{array}{l}1300 \\
1350 \\
1400 \\
1450 \\
1500 \\
1550 \\
\end{array}$ & $\begin{array}{l}0,5 \\
0,5 \\
0,6 \\
0,5 \\
0,5 \\
0,5\end{array}$ & 1,45 & 11,0 & 0,4 \\
\hline 2 & $1 / 7-1$ & 1,44 & 8,5 & $\begin{array}{l}1300 \\
1350 \\
1400 \\
1450 \\
1500\end{array}$ & $\begin{array}{l}0,5 \\
0,5 \\
0,6 \\
0,5 \\
0,5\end{array}$ & 1,66 & 9,7 & 10,6 \\
\hline 3 & $1 / 6-8$ & 1,46 & 10,2 & $\begin{array}{l}1400 \\
1450 \\
1500 \\
1550\end{array}$ & $\begin{array}{l}1,0 \\
0,5 \\
0,5 \\
0,5\end{array}$ & 1,57 & 10,9 & 8,1 \\
\hline 4 & $1 / 6-5$ & 1,50 & 9,4 & $\begin{array}{l}1450 \\
1500 \\
1550 \\
\end{array}$ & $\begin{array}{l}0,7 \\
0,5 \\
0,5 \\
\end{array}$ & 1,55 & 8,3 & 6,7 \\
\hline 5 & $1 / 7-7$ & 1,48 & 8,5 & 1500 & 0,5 & 1,56 & 7,0 & 6,4 \\
\hline
\end{tabular}


Комбинированный метод силицирования крупногабаритных изделий из УУКМ

\begin{tabular}{|c|c|c|c|l|l|l|l|l|}
\hline & & & & 1550 & 0,5 & & & \\
\hline \multirow{2}{*}{6} & \multirow{2}{*}{$1 / 6-3$} & \multirow{2}{*}{1,45} & \multirow{2}{*}{11,0} & 1400 & 1,0 & \multirow{2}{*}{1,72} & \multirow{2}{*}{6,4} & \multirow{2}{*}{16,3} \\
& & & & 1450 & 1,0 & 1,72 & \\
\hline
\end{tabular}

* Силицирование проведено при перепаде температур между парами кремния и силицируемой заготовкой $\sim 100{ }^{\circ} \mathrm{C}$, в остальных примерах - при перепаде $150{ }^{\circ} \mathrm{C}$.

После силицирования было установлено, что шликерное покрытие на основе нитрида кремния на всех образцах было провязано свободным кремнием.

В результате определения основных характеристик получившихся УККМ было установлено, что образцы из УУКМ плотностью 1,44-

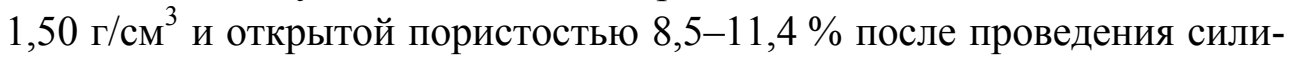

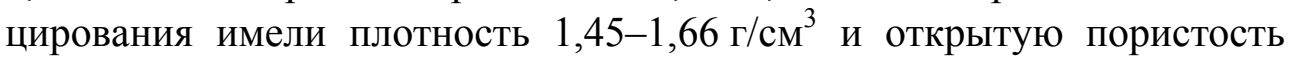
$7,0-11,0 \%$. Содержание в них кремния составило от 0,4 до 10,6 \%.

После проведения силицирования образца 1/6-3 (см. табл. 1, № 1) был получен материал с низким содержанием кремния. Это произошло из-за недостаточного перепада температур между заготовкой и тиглями с кремнием, вследствие чего не реализовалось пересыщенное состояние паров кремния.

После того, как увеличили разницу температур между заготовкой и тиглями с кремнием (за счет доработки нагревателя), провели опыт № 6. Образец 1/6-3 был силицирован повторно.

Результаты микроструктурных исследований образца 1/6-3 после повторного силицирования (с увеличением разницы температуры между заготовкой и парами кремния) представлены на рис. 2 и 3.

Исследование микроструктуры материала из образца 1/6-3 проведено методом оптической микроскопии. Исследование проводилось на металлографическом микроскопе МЕТАМ ЛВ 42 при увеличении ${ }^{\times} 100-500$, фотосъемка микроструктуры образцов - цифровой видеокамерой BR-5100LC-U. 


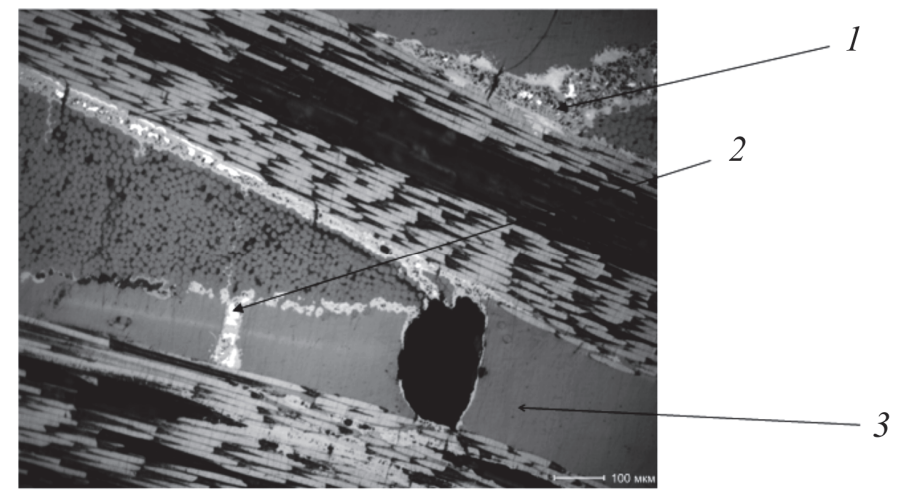

Рис. 2. Микроструктура материала образца 1/6-3 в средних по его толщине слоях (увеличение $\left.{ }^{\times} 196\right): 1$ - карбид кремния; 2 - свободный кремний; 3 - кокс

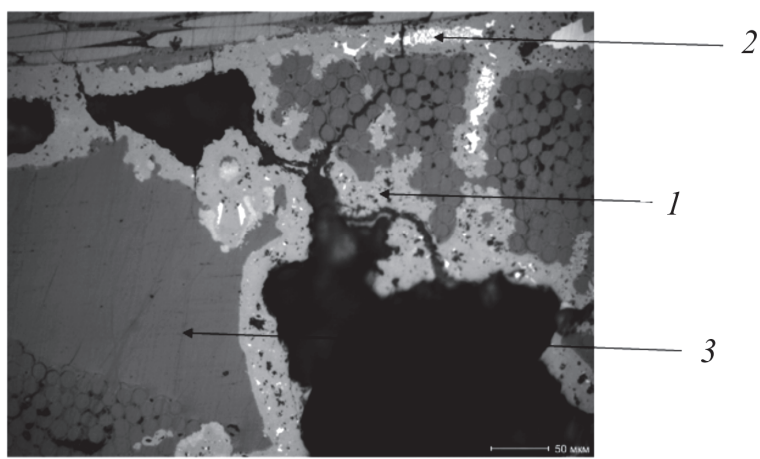

Рис. 3. Микроструктура материала образца 1/6-3 в средних по его толщине слоях (увеличение $\left.{ }^{\times} 490\right): 1$ - карбид кремния; 2 - свободный кремний; 3 - кокс

Подготовка микрошлифов образцов осуществлялась в соответствии с технологической инструкцией. Образцы предварительно были помещены в оправку из эпоксидной смолы.

Целью проведенных исследований являлось определение следующих микроструктурных характеристик образцов:

- толщины карбидокремниевого (кремниевого) покрытия;

- наличия участков карбидизации углеродных волокон;

- распределения фаз по толщине материала.

В результате микроструктурных исследований материала образца 1/6-3 установили следующее. Проникновение фаз карбида кремния и свободного кремния вглубь материала неравномерное. Заполнение фазами крупных макропор минимальное, независимо от их расположе- 
ния по толщине образца. Однако на рис. 3 видно, что на поверхности макропоры размером 250-300 мкм присутствует слой карбида кремния толщиной 25-30 мкм. Как было сказано ранее, данный слой позволит обеспечить при проведении жидкофазной стадии комбинированного силицирования (в интервале температур 1550-1700 ${ }^{\circ} \mathrm{C}$ ) защиту углеродных волокон от частичной карбидизации при взаимодействии с жидким кремнием, а самое главное - исключить науглероживание жидкого кремния.

На некоторых участках с плотной укладкой углеродных нитей фазами карбида кремния и кремния частично заполнено узкое межниточное пространство, фазы карбида кремния и свободного кремния заполняют отдельные микропоры внутри нитей, а также некоторые усадочные трещины. Обусловлено это, видимо, капиллярной конденсацией паров кремния при температурах $1300-1350{ }^{\circ} \mathrm{C}$, при которых заполняются наиболее мелкие поры. При силицировании УУКМ это нежелательный процесс, так как он может привести к частичной карбидизации углеродных волокон. Чтобы его исключить, видимо, придется капиллярную конденсацию проводить с температуры $\sim 1400{ }^{\circ} \mathrm{C}$.

\section{Реализация процесса жидкофазной пропитки предварительно силицированного материала}

На втором (заключительном) этапе реализации комбинированного метода силицирования осуществляли жидкофазную пропитку материала заготовки жидким кремнием, продуктом разложения нитрида кремния.

Как было сказано ранее, на образцах после проведения первого этапа реализации комбинированного силицирования (предварительного силицирования с задействованием процесса капиллярной конденсации паров кремния) шликерное покрытие было удалено для определения физико-химических характеристик материала. Поэтому шликерное покрытие на основе порошка нитрида кремния на образцах было сформировано заново.

Силицирование образцов на данном этапе проводили также в установке ГФ-1, но уже в обычном нагревателе при отсутствии перепада температур между тиглями с кремнием и заготовкой. В садку были установлены тигли с кремнием и образцы. 
Поскольку на образцах было вновь сформировано шликерное покрытие (т.е. не провязанное свободным кремнием), существовала опасность частичной карбидизации частиц нитрида кремния в шликерном покрытии. Для того чтобы это исключить, в интервале температур $1000-1550{ }^{\circ} \mathrm{C}$ был реализован скоростной нагрев заготовки.

Затем продолжили нагрев заготовки с 1550 до $1700{ }^{\circ} \mathrm{C}$ со скоростью $\sim 120$ град/ч. Таким образом, в период нагрева до температуры разложения нитрида кремния состояние паров кремния было близко к насыщенному, что позволяло получить в результате разложения нитрида кремния $40 \%$ жидкого кремния от стехиометрического, не содержащего в своем составе ни карбида, ни карбонитрида кремния.

После образования жидкого кремния происходила пропитка материала заготовки с заполнением уже более крупных пор. Затем произвели нагрев заготовки и тиглей с кремнием до $1800{ }^{\circ} \mathrm{C}$ при отсутствии перепада температур между ними с последующей выдержкой при $1800-1850{ }^{\circ} \mathrm{C}$ в течение 2 ч.

Охлаждение заготовки проводили в парах кремния. Это позволило заполнить кремнием открытые поры материала, оставшиеся (или образовавшиеся) после выдержки при 1700-1850 ${ }^{\circ} \mathrm{C}$.

В табл. 2 представлены результаты силицирования заготовок комбинированным методом при задействовании процесса капиллярной конденсации паров кремния.

Таблица 2

Результаты силицирования пластин комбинированным методом на базе альтернативного жидкофазного метода силицирования

\begin{tabular}{|c|c|c|c|c|c|c|c|c|}
\hline \multirow[t]{2}{*}{$\begin{array}{l}\text { № } \\
\Pi / \Pi\end{array}$} & \multirow[t]{2}{*}{$\begin{array}{c}\text { Номер } \\
\text { образца }\end{array}$} & \multicolumn{3}{|c|}{$\begin{array}{c}\text { Основные характеристики } \\
\text { материала заготовки после } \\
\text { предварительного силици- } \\
\text { рования }\end{array}$} & \multicolumn{3}{|c|}{$\begin{array}{c}\text { Основные } \\
\text { характеристики } \\
\text { УККМ }\end{array}$} & \multirow[t]{2}{*}{$\begin{array}{c}\text { Состояние } \\
\text { поверхности }\end{array}$} \\
\hline & & $\begin{array}{c}\text { Плотность } \\
\gamma, \Gamma / \mathrm{cm}^{3} \\
\end{array}$ & $\begin{array}{c}\text { ОП, } \\
\%\end{array}$ & \begin{tabular}{|c} 
Сод-е $\mathrm{Si}$, \\
вес. $\%$ \\
\end{tabular} & $\gamma, \Gamma / \mathrm{cm}^{3}$ & $\begin{array}{c}\text { ОП, } \\
\%\end{array}$ & $\begin{array}{c}\text { Сод-е } \mathrm{Si}, \\
\text { вес. } \% \\
\end{array}$ & \\
\hline 1 & $1 / 6-3$ & 1,72 & 6,4 & 16,3 & 1,85 & 4,7 & 22,1 & \multirow{4}{*}{$\begin{array}{l}\text { Чистая, без на- } \\
\text { ростов, подте- } \\
\text { ков и вымывов }\end{array}$} \\
\hline 2 & $1 / 7-1$ & 1,66 & 9,7 & 10,6 & 1,83 & 4,5 & 21,2 & \\
\hline 3 & $1 / 6-8$ & 1,57 & 10,9 & 8,1 & 1,68 & 5,9 & 13,1 & \\
\hline 4 & $1 / 6-5$ & 1,55 & 8,3 & 6,7 & 1,64 & 7,8 & 11,0 & \\
\hline 5 & $1 / 7-7$ & 1,56 & 7,0 & 6,4 & 1,77 & 6,4 & 16,3 & $\begin{array}{c}\text { Наличие вы- } \\
\text { мывных бороз- } \\
\text { док в материале } \\
\text { изделия }\end{array}$ \\
\hline
\end{tabular}


После получения положительных результатов по степени силицирования УУКМ комбинированным методом были проведены исследования физико-механических свойств получаемых УККМ.

На основе анализа результатов испытаний можно сделать вывод, что полученный в результате силицирования комбинированным методом УККМ имеет прочностные характеристики $\left(\sigma_{p}, \sigma_{\text {изг }}\right)$ выше характеристик УККМ, полученного парожидкофазным методом силицирования. При этом предел прочности при растяжении материала в направлении основы при повышении содержания в нем кремния с 7-8 до $11-15 \%$ уменьшается очень незначительно; в направлении же утка даже немного увеличивается. Это свидетельствует об отсутствии существенной карбидизации углеродных волокон. Кроме того, при плотности материала $\geq 1,67$ г/см ${ }^{3}$ и содержании кремния $\geq 11 \%$ УККМ, полученный комбинированным методом силицирования имеет значения предела прочности на изгиб выше, чем УККМ, полученный парожидкофазным методом.

В дальнейшем при проектировании конкретной композитной конструкции предполагается использование многоуровневых структурных моделей [12], которые позволят проанализировать характеристики полей деформирования с учетом статистической природы, особенностей механического поведения материала и изменений в его структуре.

\section{Заключение}

На основе анализа вышеизложенной информации можно сделать следующие выводы:

1. В результате проведенной работы экспериментально доказана возможность проведения процесса капиллярной конденсации паров кремния в низкотемпературном интервале, а именно в интервале температур $1300-1550^{\circ} \mathrm{C}$, на стадии нагрева заготовки при наличии перепада температур, что позволяет упростить его конструктивно-технологическое обеспечение в сравнении с представленным в патенте ${ }^{7}$.

2. Разработан и экспериментально опробован вариант комбинированного метода силицирования на базе альтернативного жидкофаз-

7 Способ изготовления изделий из композиционных материалов: пат. РФ № 2516096: МПК С04В35/577, С04В35/528. 
ного метода силицирования с применением процесса капиллярной конденсации паров кремния.

3. В случае реализации процесса силицирования комбинированным методом на основе альтернативного жидкофазного метода получаемый УККМ имеет содержание кремния и прочностные характеристики выше, чем УККМ, получаемый парожидкофазным методом; при этом карбид кремния и свободный кремний равномерно распределены по толщине материала.

Из вышеизложенного следует, что комбинированный метод силицирования на базе альтернативного метода перспективен для применения при силицировании крупногабаритных изделий. Однако необходимо решить вопрос по обеспечению реализации процессов капиллярной конденсации в крупногабаритных установках, таких как СШВГ.

\section{Библиографический список}

1. Кравецкий Г.А. Жидкофазная пропитка углерод-углеродных композиционных материалов с использованием технологических паст // Углеродные материалы в космической и авиационной технике: тез. докл. конф. - Киржач, 1987. - С. 44.

2. Бушуев В.М., Синани И.Л. Вопросы конструктивного оснащения процесса силицирования крупногабаритных изделий из УУКМ парожидкофазным методом // Новые технологии: материалы IX Bсерос. конф. - М.: Изд-во РАН, 2012. - Т. 2. - С. 38-45.

3. Исследование процесса силицирования жидкофазным методом с использованием в качестве силицирующего агента нитрида кремния / В.М. Бушуев, М.В. Бушуев, В.М. Блинов, Ю.А. Жуков // Перспективные материалы. - 2010. - № 9. - С. 53-57.

4. Нитрид кремния как прекурсор карбида кремния при силицировании углерод-углеродных композиционных материалов / А.Н. Тимофеев, К.В. Михайловский, И.А. Тимофеев, Е.А. Богачёв, Е.Е. Кощуг, А.В. Ширяев // Конструкции из композиционных материалов. - 2012. № 1. - C. 11-16.

5. Зависимость эффективности альтернативного жидкофазного силицирования УУКМ от давления в реакторе / В.М. Бушуев, А.С. Воробьёв, А.Г. Щурик, И.Л. Синани, М.В. Бушуев // Известия вузов. Химия и химическая технология. - 2012. - Т. 55, № 6. - С. 67-70. 
6. Исследование процесса силицирования УУКМ комбинированным методом при различных давлениях в реакторе / М.В. Бушуев, В.М. Бушуев, А.С. Воробьев, И.Л. Синани // Новые технологии: материалы IX Всерос. конф. - М.: Изд-во РАН, 2012. - Т. 2. - С. 31-37.

7. Вакуумное нанесение пленок в квазизамкнутом объеме / Ю.З. Бубнов, М.С. Лурье, Ф.Г. Старос, Г.А. Филоретов. - М.: Советское радио, 1976. - $161 \mathrm{c.}$

8. Чередниченко В.С. Дистилляционные электропечи. - Новосибирск: Изд-во НГТУ. - 2009. - 395 с.

9. Исаченко В.П. Массообмен при конденсации. - М.: Энергия, 1977. $-240 \mathrm{c}$.

10. Sokolkin Yu.V., Kotov A.G., Chekalkin A.A. Structural multistage model of the bearing capacity of carbon-carbon laminate shells // Mechanics of Composite Materials. - 1994. - Vol. 30, № 1. - P. 55-60.

11. Sokolkin Yu.V., Postnykh A.M., Chekalkin A.A. Probabilistic model of the strength, crack resistance, and fatigue life of a unidirectionallyreinforced fibrous composite // Mechanics of Composite Materials. 1992. - Vol. 28, № 2. - P. 133-139.

12. Чекалкин А.А., Паньков А.А. Лекции по механике конструкций из композиционных материалов. - Пермь: Изд-во Перм. гос. техн. ун-та, 1999. - 150 с.

\section{References}

1. Kravetskiy G.A. Zhidkofaznaya propitka uglerod-uglerodnykh kompozitsionnykh materialov $\mathrm{s}$ ispolzovaniem tekhnologicheskikh past [Liquid-phase impregnation of the carbon-carbon composite materials using technological pastes]. Tezisy dokladov konferentsii "Uglerodnye materialy $v$ kosmicheskoy i aviatsionnoy tekhnike”, 1987, p. 44.

2. Bushuev V.M., Sinani I.L. Voprosy konstruktivnogo osnashcheniya protsessa silitsirovaniya krupnogabaritnykh izdeliy iz UUKM parozhidkofaznym metodom [Questions of constructive equipping process siliconising large-sized products from the CCCM by vapor-liquid-phase method]. Materialy IX Vserossiyskoy konferentsii "Novye tekhnologii", 2012, vol. 2, pp. 38-45.

3. Bushuev V.M., Bushuev M.V., Blinov V.M., Zhukov Yu.A. Issledovanie protsessa silitsirovaniya zhidkofaznym metodom $\mathrm{s}$ ispolzovaniem $\mathrm{v}$ kachestve silitsiruyushchego agenta nitrida kremniya [The research of sili- 
conising by liquid-phase method using a silicon nitride as siliconhouse agent]. Perspektivnye materialy, 2010, no. 9, pp. 53-57.

4. Timofeev A.N., Mikhaylovskiy K.V., Timofeev I.A., Bogachev E.A., Koschug E.E., Shiryaev A.V. Nitrid kremniya kak prekursor karbida kremniya pri silitsirovanii uglerod-uglerodnykh kompozitsionnykh materialov [The silicon nitride as a precursor of silicon carbide when siliconising carbon-carbon composite materials]. Konstruktsii iz kompozitsionnykh materialov, 2012, no 1, pp. 11-16.

5. Bushuev V.M., Vorobev A.S., Shchurik A.G., Sinani I.L., Bushuev M.V. Zavisimost effektivnosti alternativnogo zhidkofaznogo silitsirovaniya UUKM ot davleniya $v$ reaktore [The dependence of the efficiency of alternative liquid-phase siliconising the CCCM on the pressure in the reactor]. Izvestiya vysshikh uchebnykh zavedeniy. Khimiya $i$ khimicheskaya tekhnologiya, 2012, vol. 55, no. 6, pp. 67-70.

6. Bushuev V.M., Bushuev M.V., Vorobev A.S., Sinani I.L. Issledovanie protsessa silitsirovaniya UUKM kombinirovannym metodom pri razlichnykh davleniyakh $\mathrm{v}$ reaktore [The research of process siliconising the CCCM by combined method at different pressures in the reactor]. Materialy IX Vserossiyskoy konferentsii "Novye tekhnologii", 2012, vol. 2, pp. 31-37.

7. Bubnov Yu.Z., Lure M.S., Staros F.G., Filoretov G.A. Vakuumnoe nanesenie plenok v kvazizamknutom obeme [Vacuum deposition of films in an quasienclosed volume]. Moscow: Sovetskoe radio, 1975. $161 \mathrm{p}$.

8. Cherednichenko V.S. Distillyatsionnye elektropechi [Distillation electric furnace]. Novosibirskiy gosudarstvennyy tekhnicheskiy universitet, 2009. $395 \mathrm{p}$.

9. Isachenko V.P. Massoobmen pri kondensatsii [Mass transfer during condensation]. Moscow: Energiya, 1977. 240 p.

10. Sokolkin Yu.V., Kotov A.G., Chekalkin A.A. Structural multistage model of the bearing capacity of carbon-carbon laminate shells. Mechanics of Composite Materials, 1994, vol. 30, no. 1, pp. 55-60.

11. Sokolkin Yu.V., Postnykh A.M., Chekalkin A.A. Probabilistic model of the strength, crack resistance, and fatigue life of a unidirectionallyreinforced fibrous composite. Mechanics of Composite Materials, 1992, vol. 28 , no. 2, pp. 133-139. 
12. Chekalkin A.A., Pankov A.A. Lektsii po mekhanike konstruktsiy iz kompozitsionnykh materialov [Lectures on mechanics of composite structures]. Permskiy gosudarstvennyy tekhnicheskiy universitet, 1999. 150 p.

\section{Об авторах}

Бушуев Вячеслав Максимович (Пермь, Россия) - кандидат технических наук, главный специалист ОАО «Уральский научноисследовательский институт композиционных материалов» (614000, г. Пермь, ул. Новозвягинская, д. 57, e-mail: uniikm@yandex.ru).

Лунегов Сергей Геннадьевич (Пермь, Россия) - инженертехнолог ОАО «Уральский научно-исследовательский институт композиционных материалов» (614000, г. Пермь, ул. Новозвягинская, д. 57, e-mail: serega.lunegov@yandex.ru).

Бушуев Максим Вячеславович (Пермь, Россия) - инженертехнолог 2-й категории ОАО «Уральский научно-исследовательский институт композиционных материалов» (614000, г. Пермь, ул. Новозвягинская, д. 57, e-mail: uniikm@yandex.ru).

\section{About the authors}

Vyacheslav M. Bushuev (Perm, Russian Federation) - Ph. D. in Technical Sciences, Chief Specialist of OJSC "Ural Research Institute of Composite Materials" (57, Novozvyaginskaya st., Perm, 614000, Russian Federation, e-mail: uniikm@yandex.ru).

Sergey G. Lunegov (Perm, Russian Federation) - Manufacturing Engineer of OJSC "Ural Research Institute of Composite Materials" (57, Novozvyaginskaya st., Perm, 614000, Russian Federation, e-mail: serega.lunegov@yandex.ru).

Maksim V. Bushuev (Perm, Russian Federation) - Manufacturing Engineer of OJSC "Ural Research Institute of Composite Materials" (57, Novozvyaginskaya st., Perm, 614000, Russian Federation, e-mail: uniikm@yandex.ru).

Получено 16.01.2015 